\title{
Role of surgery in gynaecological sarcomas
}

Review

\author{
Valentina Ghirardi ${ }^{1,2}$, Nicolò Bizzarri ${ }^{1,2}$, Francesco Guida ${ }^{1,2}$, Carmine Vascone ${ }^{1,2}$, \\ Barbara Costantini ${ }^{1,2}$, Giovanni Scambia ${ }^{1,2}$ and Anna Fagotti ${ }^{1,2}$ \\ ${ }^{1}$ Division of Gynecologic Oncology, Fondazione Policlinico Universitario Agostino Gemelli, IRCCS, Rome 00168, Italy \\ ${ }^{2}$ Catholic University of Sacred Heart, Rome 00168, Italy \\ Correspondence to: Anna Fagotti, email: anna.fagotti@unicatt.it
}

Keywords: sarcoma; uterine; cervical; ovarian; vulval

Received: November 01, $2018 \quad$ Accepted: January 19, $2019 \quad$ Published: April 02, 2019

Copyright: Ghirardi et al. This is an open-access article distributed under the terms of the Creative Commons Attribution License 3.0 (CC BY 3.0), which permits unrestricted use, distribution, and reproduction in any medium, provided the original author and source are credited.

\section{ABSTRACT}

Gynaecological sarcomas account for 3-4\% of all gynaecological malignancies and have a poorer prognosis compared to gynaecological carcinomas. Pivotal treatment for early-stage uterine sarcoma is represented by total hysterectomy. Whereas oophorectomy provides survival advantage in endometrial stromal sarcoma is still controversial. When the disease is confined to the uterus, systematic pelvic and paraaortic lymphadenectomy is not recommended. Removal of enlarged lymph-nodes is indicated in case of disseminated or recurrent disease, where debulking surgery is considered the standard of care. Fertility sparing surgery for uterine leiomyosarcoma is not supported by strong evidence, whilst available data on fertility sparing treatment for endometrial stromal sarcoma are more promising. For ovarian sarcomas, in the absence of specific data, it is reasonable to adapt recommendations existing for uterine sarcomas, also regarding the role of lymphadenectomy in both early and advanced stage disease. Specific recommendations on cervical sarcomas' surgery are lacking. Existing data on surgical approach vary from radical hysterectomy to fertilitypreserving surgery in the form of trachelectomy or wide local excision, however no definite conclusions can be drafted on the recommended surgical approach. For vulval sarcomas, complete surgical excision with at least $\mathbf{2} \mathbf{c m}$ of free margin is considered to be the primary treatment which is associated with good prognosis. The aim of this review is to provide highest quality evidence to guide gynaecologic oncologists throughout surgical management of gynaecological sarcomas.

\section{INTRODUCTION}

Gynaecological sarcomas account for approximately $3 \%$ to $4 \%$ of all gynaecological malignancies and are associated with poor outcomes compared with gynaecological carcinomas [1]. Uterine sarcomas are approximately $83 \%$ of all gynaecological sarcomas. Leiomyosarcoma (uLMS) is the most common histological sub-type, reported in $52 \%$ of diagnoses [2], and contributing to a high proportion of death for uterine tumours. For all soft tissue sarcomas, surgery remains the standard of care [3].

In this review, we summarize current available evidences on the role of surgery for uterine, ovarian, cervical and vulval sarcomas in both primary and recurrent setting, to guide surgeons throughout the management of this largely obscure and aggressive disease.

\section{MATERIALS AND METHODS}

The review of the literature included articles published from the inception until May 2018. The search was performed in the Pubmed and Embase databases and included the combination of the following Medical Subjects Heading (MeSH): 'sarcoma' \& 'gynecology', 'uterine', 'cervical', 'ovarian', 'vulvar', 'surgery', 'morcellation'. Review articles, books and monographs were also consulted. All pertinent manuscripts were included. Only papers published in English were reviewed. 
All references were reviewed in order to find other possible manuscripts to be included. The final reference list was generated on the basis of originality and relevance to the broad scope of this review.

\section{ROLE OF SURGERY IN GYNAECOLOGICAL SARCOMAS}

\section{Uterine sarcomas}

Uterine sarcomas are malignant mesenchymal tumours that account for approximately $3 \%$ of all uterine malignancies [4]. Current classification includes uLMS, the most common histological subtype (63\%), endometrial stromal sarcoma (ESS) (21\%) and high-grade or undifferentiated uterine sarcoma (UUS) (16\%) [5].

A correct pre-operative diagnosis impacts on all aspects of surgery, from the choice of surgical approach to fertility-sparing surgery.

\section{Diagnosis}

Pre-operative diagnosis of uterine sarcomas remains a challenge. Symptoms may be vague and include uterine bleeding (56\%), abdominal distention (52\%), pelvic pain or pressure $(22 \%)$, which are very similar to those presented with benign uterine conditions such as leiomyomas [3].

Moreover, there is no pre-operative test that can reliably diagnose a sarcoma unlike endometrial carcinoma, which can be detected with $90-95 \%$ sensitivity by dilation and curettage. Indeed, in a retrospective series of 938 patients with uterine cancer, preoperative sampling was significantly less reliable in predicting the correct histology for uterine sarcomas than for other histological subtypes $(64 \%$ vs. $81 \%, p<0.0001)$ [6].

In addition to that, although several features at ultrasound-scan (US-scan) and magnetic resonance imaging (MRI-scan) can raise suspicion of a uterine sarcoma, no pathognomonic images have been identified at any technique $[4,7]$. A review of MRI features of uterine sarcomas has been recently published to better define this serious condition, but there is still an overlap in imaging appearance between uLMSs and benign leiomyomas. Uterine sarcomas are more likely to be single lesions, with hyperintense signal on T1 and T2 weighed images (Table 1, Figure 1) [8].

US has been advocated as a promising diagnostic tool for these types of tumours and a lot of effort is made in these days to improve its accuracy. Exacoustos et al. have analysed number, size, echotexture, degenerative changes, and vascularity of 32 malignant uterine masses compared to 225 benign leiomyomas showing that uLMS tends to be larger, solitary lesions with increased peripheral and central vascularity [9].
Despite this, due to the rarity of these tumours, high quality data on ultrasound characteristics of myometrial masses are lacking and prospective studies are still needed (Table 1, Figure 2).

The value of raised serum lactated dehydrogenase (LDH) as an indicator of malignancy for uterine masses has been advocated. Particularly, together with patient's older age, it has been found to be a significant predictor for malignancy at multivariate analysis in a retrospective analysis of 63 uterine masses [10].

Although it cannot be considered a diagnostic test, it has been suggested that the combination of degenerative changes within the uterine mass and an increased LDH level, should raise the suspicion of uLMS [11].

As per all soft tissue sarcomas, the role of preoperative needle biopsy may represent an option either to avoid unnecessary surgeries, or to choose type of surgery in patients with suspicious uterine masses. Kawamura et al. [12] investigated the accuracy of needle biopsy for uterine myoma-like tumours in 2002. They performed transcervical biopsy in 435 women with uterine masses. Out of them, 7 were confirmed to be uterine sarcomas at final histology and 4 out 7 had a preoperative diagnosis with needle biopsy. They therefore concluded that trans-cervical needle biopsy is a reliable diagnostic test for the differential diagnosis between uterine sarcoma and leiomyoma.

Other more recent evidences have shown sensitivity and specificity of trans-peritoneal biopsy of $92.5 \%$ and $100 \%$ respectively [13], but no data on survival of patients with biopsied uLMSs is currently available. Indeed, although trans-cervical biopsy may limit the risk of disease spread within peritoneal cavity, it may not reach all uterine masses. On the other hand, trans-peritoneal USguided biopsy can be performed for all uterine masses, but it raises concerns regarding potential intraperitoneal disease dissemination.

Due to all these diagnostic limitations, a preoperative diagnosis is quite uncommon. Most women with early stage uterine sarcomas undergo surgery for presumed benign conditions and surgeons have to face a potentially complex surgery with no certainty on diagnosis.

\section{Surgical treatment of uterine sarcoma confined to the uterus}

As per all soft tissue sarcoma, for uterine sarcomas surgery is the standard of care and provides a survival advantage. Resection of disease without fragmentation and with negative surgical margins is the gold standard for treatment $[3,14]$. Total hysterectomy $(\mathrm{TH})$ and bilateral salpingo-oophorectomy (BSO) are the standards of care in the management of early stage uterine sarcomas [4].

For both uLMS and ESS, the risk of lymph node metastases has been reported respectively as 3\% and $<10 \%$, therefore routine lymphadenectomy is not generally recommended in early stage disease (unless suspicious 
Table 1: MRI and US features suggestive for uterine sarcoma $[8,9]$

\begin{tabular}{ll}
\hline MRI features & \multicolumn{1}{c}{ US features } \\
\hline Single lesion with irregular margins & Large lesion $(>8 \mathrm{~cm})$ \\
Endometrial thickening & Solid mass \\
Ascites & Increased central and peripheral vascularity \\
Hyperintense in T2-weighed images & Degenerative cystic changes \\
Hyperintense in T1 weighed images & No acustic shadowing \\
\hline
\end{tabular}
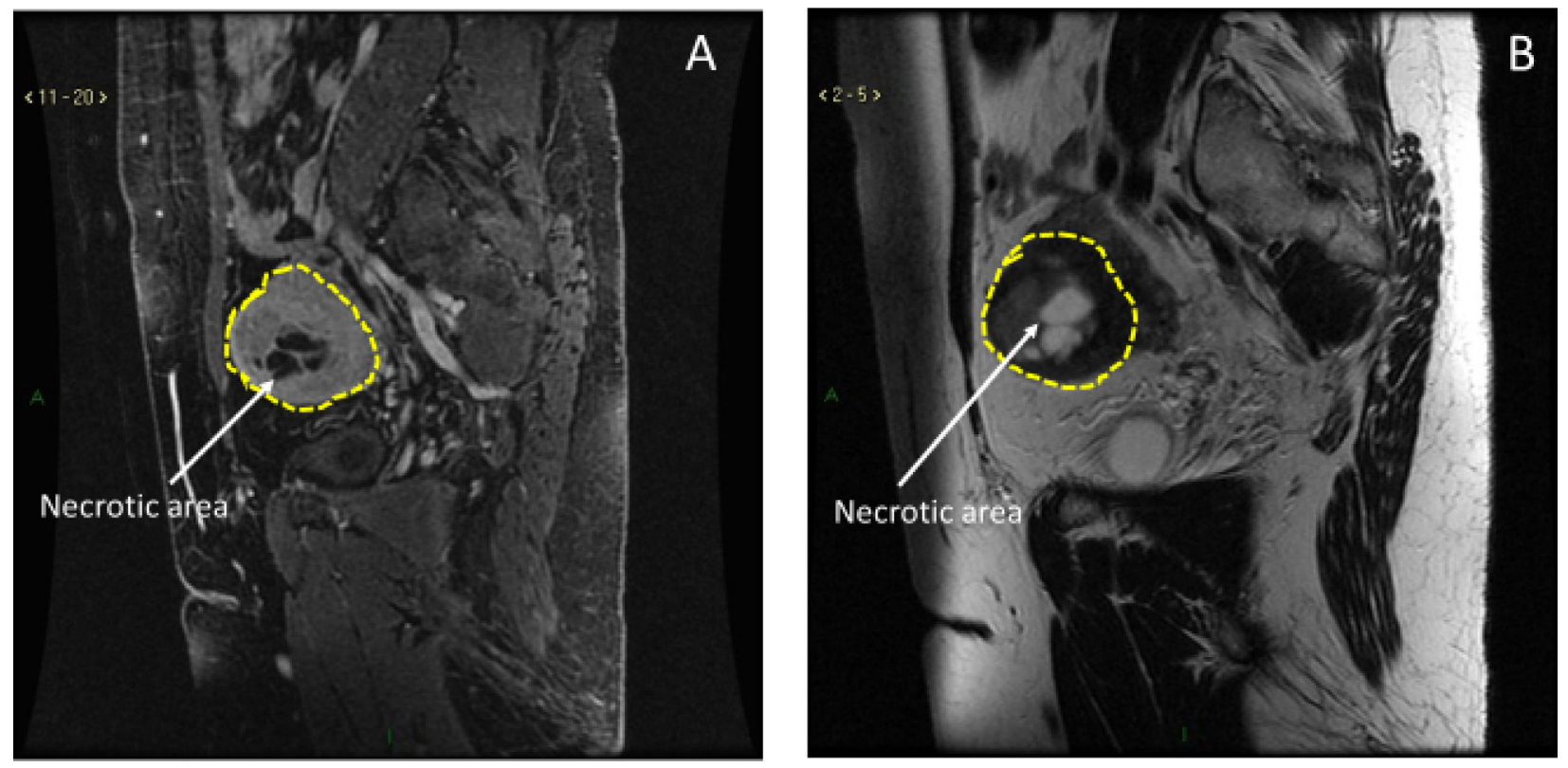

Figure 1: MRI characteristics of uLMS. (A) Hyperintense signal in T1-weighed images. (B) Hyperintense signal in T2-weighed images.

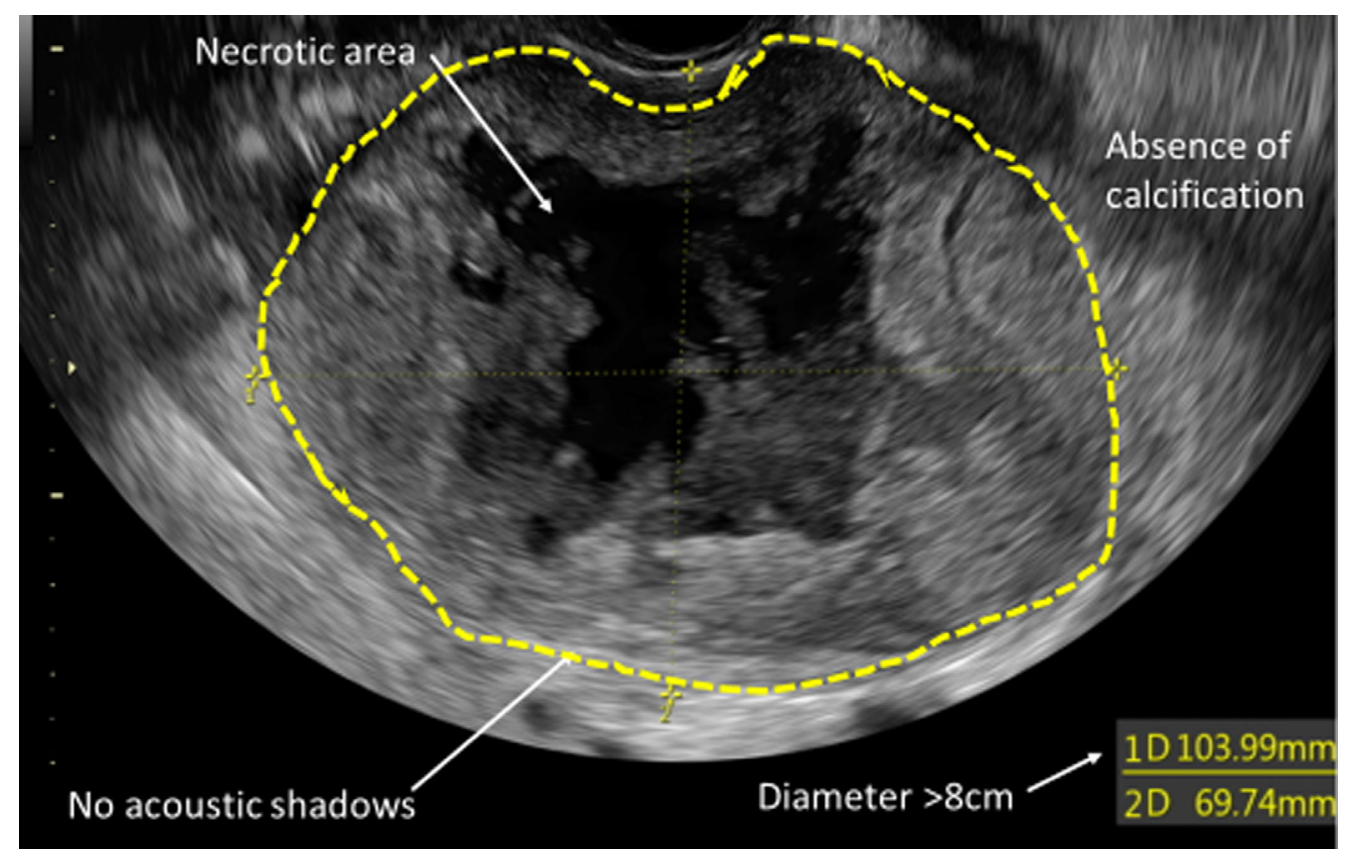

Figure 2: US characteristics of uLMS. 
lymphadenopathy is noted on pre-operative imaging or intra-operative findings) to reduce the morbidity related to the procedure [15].

A retrospective evaluation of 1010 ESS patients by Barney et al. showed that only age, tumour grade and FIGO stage had a negative impact on survival at multivariate analysis. Adding lymphadenectomy to hysterectomy and BSO did not change survival [16].

The same results are described in a recent retrospective analysis of a large cohort of uLMS patients carried out by Seagle et al. where early and complete resection was the best-evidenced treatment for uLMS. Omitting lymphadenectomy was not associated with survival [17].

Regarding the role of oophorectomy in premenopausal women with uLMS, data remain unclear. A retrospective review of 1395 leiomyosarcoma patients showed that independent predictors for disease specific survival included age, race, stage, grade, and primary surgery. Oophorectomy did not impact on survival [18]. Overall, since the risk of ovarian metastases has been reported as $4 \%$, ovarian conservation may be considered, without compromising survival outcome, on a caseby-case assessment, only with documented negative endocrine receptor-status $[15,19]$.

Data on ovarian conservation for ESS are controversial as well. A recent review of 112 patients with low-grade ESS supported the role of oophorectomy to prolong progression-free survival [20].

Uncertainty on this topic is shown in another recent review published by Nasioudis et al. They included a cohort of 1482 women affected by uterine sarcoma limited to the uterus. Oophorectomy was not associated with worse oncologic outcomes for women with uLMS, but no conclusions could be made for those with low gradeESS where ovarian preservation was associated with comparable OS $(p=0.410)$ and cancer specific survival $(p=0.560)$ rates [21]. Also, another series reported no impact on survival for low grade-ESS patients treated with ovarian preservation [22]. Overall, despite further evidences are needed, we can conclude that $\mathrm{TH}$ with BSO should be the initial and salvage mainstay treatments for low grade-ESS patients. Ovary-sparing procedures could be considered in young, extensively counselled women, depending on tumour hormonal receptor status; however, long-term follow-up should be mandatory [23]. Regarding high-grade undifferentiated sarcomas, surgery involving $\mathrm{TH}$ and $\mathrm{BSO}$ is recommended due to the aggressiveness of the disease [24].

\section{Role of morcellation}

With the advent of minimally invasive surgery, laparoscopic morcellation has allowed surgeons to remove large uterine myomas without having to perform open surgery. This has also guaranteed women to experience a reduced number of perioperative complications and a faster recovery [3].

In November 2014, as the risk of morcellating an occult uterine sarcoma could worsen survival outcomes due to potential intra-abdominal disease dissemination, the U.S. Food and Drug Administration (FDA) released a safety communication with a warning regarding the use of the electromechanical morcellator devices for women undergoing myomectomy/hysterectomy [25]. However, some criticisms have been raised with the time at the FDA report. Overall, the risk of morcellating an occult malignancy estimated in the FDA review was 1:352 for any uterine malignancy and 1:498 for uLMS.

Many criticisms have been raised to this report, such as the lack of information regarding the screening process of women undergoing uterine morcellation in the studies included in FDA review [26, 27]. On this topic, a large study was performed at John Hopkins Hospital, which included 2,137 appropriately screened hysterectomy and myomectomy cases. They found only one case in which a woman underwent morcellation of an occult uterine sarcoma over a 10-year period [28].

Because of all the criticisms related to FDA report, several large studies have estimated that the incidence of occult uterine sarcoma in women undergoing surgery for presumed benign fibroids was actually much lower than that quoted by the FDA, on the order of 1 in 1,700 to 7 in 100,000 women undergoing hysterectomy $[29,30]$.

On the other hand, several studies have put some effort to sustain the FDA communication. In a recent systematic review and meta-analysis of 60 studies, Bogani et. al found that morcellation was an independent negative prognostic factor for survival. It was found to increase the overall (62\% vs. 39\%; OR: 3.16 (95\% CI: $1.38,7.26))$ and intra-abdominal recurrence rate $(39 \%$ vs. $9 \%$; OR: $4.11(95 \%$ CI: $1.92,8.81))$ as well as the death rate ( $48 \%$ vs. $29 \%$; OR: 2.42 ) [31]. Superimposable results have been reported in a review by the MITO group, suggesting that morcellation increases the risk of death in patients affected by undiagnosed uLMS [32]. Since uLMS has a high recurrence rate after surgery, the real impact of morcellation on survival is not frankly addressable. However, this procedure may have a more detrimental impact on survival of patients with disease with a lower risk of dissemination, such as low-grade ESS or smooth muscle tumour with uncertain potential (STUMP) [33].

Is therefore true that power morcellation is a dangerous procedure and should be abandoned? Due to the variety of evidences available in literature, a definite conclusion cannot be drafted, and high-quality prospective studies should be undertaken to address this topic. However, it seems useful to underline some bullet points that should be considered in daily practice: i) avoid morcellation when malignancy is suspected; ii) carry out an accurate pre-operative workup to minimise the risk of an undiagnosed occult malignancy [34]; iii) adequate 
counsel the patient regarding risk to benefit ratio of any proposed procedure. If the decision of a minimallyinvasive approach is made and morcellation is an option, contained morcellation into insufflated isolation bags or transvaginal specimen retrieval via endoscopic bags, may represent two promising techniques for a safe specimen extraction.

On this extensive background, practical surgical data on how to behave after an accidental morcellation of a sarcoma need to be provided in this manuscript. Completion hysterectomy or trachelectomy if a supracervical hysterectomy has been previously performed, peritoneal biopsies, omentectomy/omental biopsy are advised by multiple investigators. Surgical re-exploration is likely to show findings of disseminated peritoneal sarcomatosis in a significant number of patients diagnosed with uLMS after a morcellation procedure $[35,36]$. If that is the case, a cytoreductive procedure is recommended.

\section{Fertility-sparing surgery}

Fertility sparing surgery in uterine sarcomas is an extremely critical subject. In the current literature a limited number of authors have investigated this topic and very few evidences can support this management, which can sometimes be advocated when the sarcoma diagnosis follows a myomectomy in a young and nulliparous patient.

At best of our knowledge, the only series on conservative management for fertility purposes for uLMS was published in 1998 and included 8 patients with a diagnosis of uLMS following myomectomy between 1982 and 1996. Median follow-up was 42 months. 3 pregnancies were recorded and 2 of them had spontaneous delivery at term. The third patient was found to have disseminated disease at the time of caesarean section and died of the disease 26 months after the diagnosis. Basing on their experience, the authors concluded that selected cases of uLMS might be managed conservatively in nulliparous women desiring pregnancy. A strict follow-up is mandatory and at the completion of the reproductive life, a demolitive procedure could be considered [37]. Considering the difficulties in the histological recognition of this disease and the need for histopathological review at referral centres, the different clinical behaviour of these patients may be explained by an incorrect primary diagnosis. Of note, two patients who received a second operation, 24 and 16 months after the first surgery, were found to have benign leiomyomas.

Some successful pregnancies have been reported for ESS conservatively managed; however, data on survival are limited [38, 39].

Overall in literature, 34 cases of ESS conservatively managed are reported and among them, 17 patients $(50 \%)$ conceived. Fifteen recurrences are documented after a median follow-up of 15 months (range 3-52) with only one death of disease [40].
For all these reasons, it is our opinion that due to the lack of strong evidences and the aggressive nature of those tumours, fertility sparing surgery for uLMS is still an experimental procedure and should not be recommended until more evidences are provided. However, survival data for ESS patients conservatively managed are more reassuring and it can therefore represent an option in selected and extensively counselled nulliparous women.

\section{Surgical treatment for advanced and recurrent disease}

As described by multiple evidences, main treatment for advanced stage uterine sarcoma remains surgery. For uLMS, aggressive cytoreduction seems to be associated with prolonged survival [41], even if in some series, survival improvement after cytoreduction in advanced stage disease is found only for progression-free but not for overall survival. Therefore, selection of surgical candidates needs to be addressed carefully and the improvement in PFS must be weighed against the morbidity of surgery [42].

The same conclusions can be drafted for ESS. A systematic review showed that surgical resection is appropriate for both patients with early-stage (I or II) disease and those with resectable, advanced-stage (III or IV) tumours [43]. Moreover, removal of bulky lymph nodes needs to be considered as part of the cytoreductive procedure, thus inspection is recommended [4].

Few evidences show that surgery may have a role also in the recurrent setting of uterine sarcoma. In a retrospective study performed by Giuntoli et al., secondary cytoreductive surgery was found to prolong survival in a selected group of patients with uLMS. Interestingly in their series, neither chemotherapy nor radiation therapy were associated with an improved outcome in this group of patients [44]. The same result was achieved in a more recent Japanese retrospective study, which included 18 women with recurrent uterine sarcoma. They found that secondary cytoreductive surgery led to a survival advantage in this group of patients [45].

Interestingly, the role of hyperthermic intraperitoneal chemotherapy (HIPEC) associated with cytoreductive surgery has been investigated by few studies with good outcomes, whilst evidence on the role of neoadjuvant chemotherapy in this setting are very scanty. A recent retrospective study comparing overall survival of 25 patients with recurrent uterine sarcoma showed survival benefit of the group receiving surgery with subsequent HIPEC compared to surgery followed by chemotherapy or radiotherapy, surgery only or medical treatment alone [46].

Overall, despite all surgical and medical efforts to provide adequate and life-prolonging treatments, prognosis of uterine sarcoma remains quite poor, being recurrence rate after surgery between $50 \%$ and $70 \%$ and five-year survival rate as low as $30 \%$ [47]. It has been shown by multiple evidences that advanced age seems 
to be associated with unfavourable clinical outcome. Particularly, in a retrospective series of $51 \mathrm{uLMS}$ patients, age older than 50 years old was associated with an 11.07 increased risk of death $(p=0.017)$ at multivariate analysis. [48-50] (Table 2). However, available results on the role of surgery associated with HIPEC seem to be quite promising, therefore further studies on this topic are encouraged.

Recommendations for surgical management of uLMS and ESS are summarised in Table 3.

Supplementary Table 1 shows an overview of main studies on the role of surgery in uterine sarcoma.

\section{Ovarian sarcomas}

Ovarian sarcomas are a very rare entity comprising only $1 \%$ of ovarian tumours and available data are limited. These neoplasms have a poorer prognosis compared to epithelial ovarian cancers for all FIGO stages, as shown in a recent retrospective case-control match study [51]. Throughout literature, the most common entities described are ovarian leiomyosarcomas and most of the evidences are in the form of case reports and case series. Primary ovarian leiomyosarcoma (POLMS) is a rare disease with a worse prognosis when compared to their uterine counterpart, diagnosed at the same stage. The prognostic factors that influence overall survival most are tumour stage, size, grade, and mitotic index [51, 52].

These high-risk tumours can arise from smooth muscle of the blood vessels walls, in the cortical stroma, in the corpus luteum, and in the attachment of ovarian ligaments. Interestingly, they can also be of extra-ovarian vascular origin. In particular, primary leiomyosarcomas arising from the ovarian vein have been described as aggressive neoplasms [53].

The diagnostic criteria for ovarian leiomyosarcoma are similar to those used for the uterine counterpart [54].

At best of our knowledge, less than 50 cases of POLMS cases have been reported in the English literature. In all reported cases initial treatment was surgery. The extent of surgery was variable from fertility-preserving operations to complete surgical staging. Adjuvant treatment, either chemo or radiation therapy was administered to many of those cases [51]. Among them, 11 deaths of disease were documented. The longest FU was 118 months.

Of note, POLMS can also arise in the background of a benign ovarian neoplasm. Interestingly, the synchronous presence of a leiomyosarcoma and an ovarian fibroma in a single ovary has been documented in one case whilst in 4 other cases, the leiomyosarcoma was arising in a mature cystic teratoma of the ovary $[55,56]$.

Regarding surgical treatment of POLMS, up to now there are no prospective studies to define management recommendations for these rare entities. In the absence of specific data, it is reasonable to adapt recommendations from data existing for uLMS. Specifically, for disease limited to the ovary, $\mathrm{TH}$ and BSO are recommended. As per uLMS, the likelihood of lymph node metastases or occult malignancy is low, therefore for patients who did not have lymphadenectomy or omentectomy at the time of initial surgery a second operation is not recommended [54]. In the setting of advanced or recurrent disease, reported data are even fewer and, at best of our knowledge, only a small amount of case report is available on this topic. Overall, patients presenting with relapsed disease are candidates for palliative treatment and succumb to their disease within a few months [57]. However, in some cases surgical treatment has demonstrated to prolong survival. Particularly, removal of scalp and liver metastases from POLMS has prolonged survival in two cases $[58,59]$. The same result is achieved in a third case with the removal of a large abdominal recurrence 7 months after primary surgery [60].

Ovarian sarcomas include some other less frequent entities such as fibrosarcoma or rhabdomyosarcoma [58], whereas extra-uterine ESS are conventionally referred to as "endometrioid stromal sarcomas" when they arise outside the uterus. For primary endometrioid stromal sarcomas of the ovary scanty data on their behaviour and optimal treatment are available. To date, less than 100 cases of ovarian endometrioid stromal sarcomas have been reported and since most series included both primary and metastatic cases, defining the features of pure ovarian endometrioid stromal sarcomas has been difficult. The largest series of 14 cases has been recently published [61]. The median age at diagnosis was 51.5 years (range 34-61 years), 8 patients underwent TH with $\mathrm{BSO}$, whilst 3 women underwent BSO only because of a previous hysterectomy for benign conditions. The remaining three cases included patients presented with recurrent disease who were initially treated with $\mathrm{TH}$ and unilateral salpingo-oophorectomy or BSO only. The median follow-up was 65 months (range 8-311 months). Of the 9 low-grade endometrioid stromal sarcomas cases, 3 developed intraabdominal recurrence at 8-30 and 52 months after surgery with no reported deaths. Of the remaining 5 patients with high-grade endometrioid stromal sarcomas, one was alive and disease free and 4 developed recurrence at 8-12-22 and 24 months after surgery. All patients with recurrent disease were treated with debulking surgery and adjuvant therapy. Of them, 2 succumbed of the disease. Because it may be very challenging to differentiate a primary endometrioid stromal sarcomas from an ovarian metastasis, a thorough analysis of the uterine status is recommended. To conclude, as per other ovarian sarcomas, surgery including $\mathrm{TH}$ and BSO is the mainstay of treatment. Tumour debulking should be reserved for advanced stage disease. Despite it does not seem to improve survival, evidences on the role of lymphadenectomy have been elusive $[61,62]$. 
Table 2: Adverse prognostic factor for uterine sarcoma $[48,49]$

FIGO stage $>$ II

Age $>50$ year old

Tumour size (5-years OS: size $<50 \mathrm{~mm}$ : 64.0\%; 50-100 mm 56.4\%; >100 mm 29.3\%)

Negative progesterone receptor status

High mitotic count (cut-off $>10$ mitoses/10 HPF)

High preoperative CRP serum level (cut-off $>3.5 \mathrm{mg} / \mathrm{dL}$ )

HPF: high-power field; CRP: C-reactive protein

Table 3: Recommendations for surgical management of uLMS and ESS

\begin{tabular}{lccc}
\hline Procedure & uLMS & ESS & $\begin{array}{c}\text { Level of } \\
\text { Evidence }\end{array}$ \\
\hline Total hysterectomy & Recommended & Recommended & IV \\
Bilateral salpingo-ophorectomy & Recommended & Recommended & IV \\
Systematic lymphadenectomy in stage I & Not recommended & Not recommeded & Recommended \\
$\begin{array}{l}\text { Debulking surgery in case of } \\
\text { disseminated disease }\end{array}$ & Recommended & Not recommended \\
Ovarian preservation in young women & Optionable, if negative & IV \\
Fertility sparing surgery & ER-PR status & Optionable in selected & IV \\
\hline
\end{tabular}

I. Evidence from at least one large randomised, controlled trial of good methodological quality (low potential for bias) or meta-analyses of well conducted randomised trials without heterogeneity

II. Small randomised trials or large randomised trials with a suspicion of bias (lower methodological quality) or meta-analyses of such trials or of trials with demonstrated heterogeneity

III. Prospective cohort studies

IV. Retrospective cohort studies or case-control studies

V. Studies without control group, case reports, experts' opinions

Table 4 presents an overview of main studies on the role of surgery in ovarian sarcoma.

\section{Cervical sarcomas}

Cervical sarcomas account for less than $1 \%$ of all cervical malignancies. Most of the patients present with vaginal bleeding and a bulky cervical mass at the time of diagnosis [63].

Due to the relative infrequency of the disease, most of the available data on the natural history of cervical sarcomas are derived from case reports and small case series, thus leading to paucity of information regarding the clinical features, treatment modality and prognosis of patients [64]. The largest available series of cervical sarcomas identified 323 cases among 33,074 patients with cervical cancer treated over nearly 17 years. Compared to women with squamous cell carcinoma and adenocarcinoma, patients with cervical sarcomas tended to be younger, have larger tumours, and have more advanced stage disease with worse prognosis with respect to the epithelial counterpart matched by stage [65].
Among all the subtypes, rhabdomyosarcoma of embryonal subtype is the most frequently reported in young patients. In a retrospective review of 11 patients by Kriseman et al., information regarding this rare histological entity were collected from 1980 to 2010 at MD Anderson Cancer Centre. All patients underwent surgery at some stage of their treatment, 9 as upfront surgery and 2 after medical treatment. In their series, 1 patient died for the disease and 1 died for complication related to chemotherapy [66].

Overall, the prognosis associated with cervical rhabdomyosarcoma appears to be favourable. In particular, classical embryonal rhabdomyosarcoma, most commonly presenting with a polypoid (exophytic) growth pattern, is associated with better prognosis. Among the embryonal subtypes, the botryoid variant is associated with better outcomes [67].

Since such a few evidences on this topic are available in literature, it is difficult to draw broad conclusions on treatment modality. However, it appears that surgery and chemotherapy are the mainstays of treatment of cervical rhabdomyosarcoma. The surgical 
Table 4: Overview of main studies on the role of surgery in ovarian sarcoma

\begin{tabular}{|c|c|c|c|c|c|c|c|c|}
\hline Author & Year & $\begin{array}{l}\text { Number } \\
\text { of patients }\end{array}$ & Type of study & Setting & Treatment & Survival & Conclusion & Note \\
\hline $\begin{array}{l}\text { Bacalbasa et al. } \\
\text { [51] }\end{array}$ & 2014 & 11 & $\begin{array}{l}\text { Retrospective } \\
\text { case control } \\
\text { matched study }\end{array}$ & $\begin{array}{l}\text { Prognosis } \\
\text { of Ovarian } \\
\text { leiomyosarcoma } \\
\text { compared } \\
\text { to epithelial } \\
\text { counterpart }\end{array}$ & Surgery $+\mathrm{CT}$ & $\begin{array}{l}\text { FIGO stage II OS } \\
113 \text { months epithelial } \\
\text { carcinomas vs } 90.5 \\
\text { months for sarcomas } \\
\text { ( } p<0.048) \text {; FIGO } \\
\text { stage IIIC OS } \\
51 \text { months epithelial } \\
\text { carcinomas vs } 20 \\
\text { months for sarcomas } \\
\text { in patients requiring } \\
\text { multiple visceral } \\
\text { resections. } \\
\text { OS } 61 \text { months } \\
\text { epithelial carcinomas } \\
\text { vs 9months for } \\
\text { sarcomas in patients } \\
\text { not requiring } \\
\text { multiple visceral } \\
\text { resections. DFS } \\
4.5 \text { months for } \\
\text { ovarian sarcomas } \\
\text { vs } 23.6 \text { epithelial } \\
\text { carcinomas. } \\
\text { Secondary } \\
\text { cytoreduction did not } \\
\text { impact on survival }(p \\
<0.007) \text { FIGO stage } \\
\text { IV OS for sarcoma } \\
\text { patients } 2 \text { months } \\
\text { vs } 9 \text { months for } \\
\text { epithelial carcinomas } \\
(p<0.09)\end{array}$ & $\begin{array}{l}\text { DFS and OS } \\
\text { are lower for } \\
\text { patients with } \\
\text { ovarian sarcomas } \\
\text { compared } \\
\text { to epithelial } \\
\text { carcinomas }\end{array}$ & $\begin{array}{l}\text { Patients } \\
\text { treated } \\
\text { from } 2002 \\
\text { to } 2013\end{array}$ \\
\hline $\begin{array}{l}\text { López-Ruiz et al. } \\
\text { [53] }\end{array}$ & 2017 & 1 & Case report & $\begin{array}{l}\text { Primary } \\
\text { leiomyosarcoma of } \\
\text { ovarian vein }\end{array}$ & Surgery $+\mathrm{CT}$ & $\begin{array}{l}\text { Recurred } 17 \text { months } \\
\text { after surgery (distant } \\
\text { metastases) }\end{array}$ & $\begin{array}{l}\text { Primary } \\
\text { leiomyosarcomas } \\
\text { arising from the } \\
\text { ovarian vein } \\
\text { are aggressive } \\
\text { neoplasms, and } \\
\text { the prognosis } \\
\text { correlates with } \\
\text { stage. }\end{array}$ & \\
\hline $\begin{array}{l}\text { He } \text { et al. } \\
{[55]}\end{array}$ & 2016 & 1 & Case report & $\begin{array}{l}\text { Synchronous } \\
\text { leiomyosarcoma } \\
\text { and fibroma in a } \\
\text { single ovary }\end{array}$ & Surgery $+\mathrm{CT}$ & $\begin{array}{l}\text { Recurred after } 13 \\
\text { months (peritoneal } \\
\text { disease) }\end{array}$ & $\begin{array}{l}\text { It is hypothesized } \\
\text { that the poor } \\
\text { prognosis is } \\
\text { associated with } \\
\text { the co-occurrence } \\
\text { of POLMS and } \\
\text { fibroma, which } \\
\text { increased the } \\
\text { uncertainty of } \\
\text { treatment and } \\
\text { therapeutic effects }\end{array}$ & - \\
\hline $\begin{array}{l}\text { Pongsuvareeyakul et al. } \\
\text { [56] }\end{array}$ & 2017 & 1 & Case report & $\begin{array}{l}\text { Leiomyosarcoma } \\
\text { and Squamous Cell } \\
\text { Carcinoma Arising } \\
\text { in Mature Cystic } \\
\text { Teratoma of the } \\
\text { Ovary }\end{array}$ & Surgery & $\begin{array}{l}\text { Disseminated disease } \\
\text { at presentation, died } \\
30 \text { days after surgery } \\
\text { for postoperative } \\
\text { complications }\end{array}$ & - & - \\
\hline $\begin{array}{l}\text { Bacalbasa et al. } \\
{[58]}\end{array}$ & 2016 & 1 & Case report & Recurrent disease & Surgery & $\begin{array}{l}\text { Recurrence occurred } \\
5 \text { years after } \\
\text { diagnosis and was } \\
\text { treated with surgery. } \\
\text { Alive at } 2 \text { years of } \\
\text { follow up }\end{array}$ & - & - \\
\hline $\begin{array}{l}\text { Sultana et al. } \\
\text { [59] }\end{array}$ & 2009 & 1 & Case report & Recurrent disease & Surgery $+\mathrm{CT}$ & $\begin{array}{l}\text { Recurred } 18 \text { months } \\
\text { after diagnosis. No } \\
\text { data on follow up }\end{array}$ & - & - \\
\hline $\begin{array}{l}\text { Rasmussen et al. } \\
{[60]}\end{array}$ & 1997 & 1 & Case report & Recurrent disease & $\begin{array}{l}\text { Surgery }+\mathrm{CT} \\
\text { at primary } \\
\text { diagnosis. } \\
\text { Surgery only at } \\
\text { recurrence. }\end{array}$ & $\begin{array}{l}\text { First recurrence after } \\
41 \text { months. } \\
\text { Second recurrence } \\
70 \text { months } \\
\text { after secondary } \\
\text { cytoreduction. Alive } \\
\text { at } 7 \text { years of follow up }\end{array}$ & & \\
\hline
\end{tabular}




\begin{tabular}{|c|c|c|c|c|c|c|}
\hline $\begin{array}{l}\text { Xie et al. } \\
{[61]}\end{array}$ & 2017 & 14 & $\begin{array}{l}\text { Retrospective } \\
\text { study }\end{array}$ & $\begin{array}{l}\text { Clinicopathologic } \\
\text { and outcome of } \\
\text { primary ovarian } \\
\text { ESS patients }\end{array}$ & $\begin{array}{l}\text { Surgery: } 14 \\
\text { CT: } 10 \\
\text { RT: } 2 \\
\text { HT: } 3\end{array}$ & $\begin{array}{l}\text { At a median follow } \\
\text { up of } 65 \text { months } \\
\text { (range } 8-311 \\
\text { months): } \\
\text { All } 9 \text { low grade } \\
\text { ESS patients were } \\
\text { alive } \\
3(33.3 \%) \text { recurred } \\
\text { after surgery } \\
\text { Among } 5 \text { high } \\
\text { grade ESS patients: } \\
1(20 \%) \text { did not } \\
\text { recur and was alive } \\
4(80 \%) \text { recurred } \\
2(40 \%) \text { died of } \\
\text { disease }\end{array}$ \\
\hline $\begin{array}{l}\text { Geas et al. } \\
{[62]}\end{array}$ & 2004 & 1 & Case report & $\begin{array}{l}\text { Primary ESS arising } \\
\text { from endometriosis }\end{array}$ & Surgery + HT & $\begin{array}{l}\text { No evidence of } \\
\text { recurrence at follow } \\
\text { up }\end{array}$ \\
\hline
\end{tabular}

"ESS: endometrioid stromal sarcoma; "FU: follow up; "CT: chemotherapy; "RT: radiotherapy; "HT: hormonal therapy. DFS: disease free survival; OS: overall survival; CT: chemotherapy; POLMS: primary ovarian leiomyosarcoma; ESS: endometrioid stromal sarcoma; RT: radiotherapy; HT: hormonal therapy

approaches described in literature for these extremely uncommon entities vary from radical hysterectomy to fertility preserving surgery in the form of radical/simple trachelectomy or wide local excisions. However, the paucity of cases described, and the lack of survival data do not allow to identify the recommended surgical approach $[68,69]$. For the same reason, no definite answer can either be given on impact of nodal metastases on survival and therefore on the role of lymphadenectomy [70].

Leiomyosarcomas arising in the uterine cervix are exceedingly rare tumours. They tend to arise in the perimenopausal period with abnormal vaginal bleeding as the most common presenting symptom.

Due to limited evidences, we must accept means of managing uLMS for guidance, i.e. TH and BSO. The role of lymphadenectomy is limited due to the low rate of lymphatic spread. Metastases are more likely to be found when the nodes are grossly enlarged or in the setting of obvious intra-abdominal disease [70].

Despite a thorough literature search on this topic, all available evidences appear not to be up to date.

Table 5 shows an overview of main studies on the role of surgery in cervical sarcoma.

\section{Vulval sarcomas}

Vulval sarcomas account for $1-3 \%$ of all vulval cancers. The most common vulval sarcomas are leiomyosarcomas, followed by other less frequent histologic types, like angiosarcomas, malignant peripheral nerve sheath tumours, and malignant fibrous histiocytomas [71, $72]$.

Vulval rhabdomyosarcoma is more frequent in childhood and adolescence and comprises more than a half of soft tissue sarcomas in paediatric patients. The adult variant is associated with a poorer prognosis [73].

All of these tumours are characterised by no-specific symptoms and are often confused with benign conditions, such as Bartolin's cyst or vulval abscesses. Symptoms may include chronic vulval pruritus, vulval mass or longstanding pain. [74].

The prognosis of these neoplasms is generally poor. They tend to have rapid growth, high metastatic potential, frequent recurrences, aggressive behaviour, and high mortality rate [71].

For diagnostic purposes, tumours showing three or all of the four following features should be considered as sarcomas: $\geq 5 \mathrm{~cm}$ in greatest dimension, infiltrative margins, $\geq 5$ mitotic figures per 10 high power field, and moderate to severe cytologic atypia [75].

Most of the available literature on management of vulval sarcomas is based on case reports and, as per all gynaecological sarcomas, evidences are lacking, and no definite algorithms are available.

However, complete surgical excision with negative margins is considered to be the primary treatment, which is associated with good prognosis. For residual tumour, combined chemotherapy and radiotherapy is advocated $[75,76]$.

This data is also confirmed by a series of 24 women with vulval (9 patients) and vaginal (15 patients) sarcoma published by Curtin et al. [77]. They performed surgical excision with free margins as primary treatment in 23 of them, without adjuvant therapy. Among the vulval sarcoma cases, only one out of 7 patients with low-grade leiomyosarcoma recurred locally after this treatment. Basing on their experience, surgery should be considered the primary therapy for those neoplasms, whereas adjuvant treatment is indicated in high-grade tumours or locally recurrent low-grade sarcomas.

In a retrospective study performed by Aarsten et al., no difference was found in the biological behaviour of vulval sarcomas, when compared to sarcomas originating in other parts of the body. For all histologic types excepting epithelioid sarcomas, wide surgical excision was associated with improved prognosis. Moreover, neither elective groin node dissection, nor excision of enlarged inguinal lymph nodes was beneficial in most of the cases [76]. 
Table 5: Overview of main studies on the role of surgery in cervical sarcoma

\begin{tabular}{|c|c|c|c|c|c|c|c|c|}
\hline Author & Year & $\begin{array}{c}\text { Number } \\
\text { of } \\
\text { patients }\end{array}$ & Type of study & Setting & Treatment & Survival & Conclusion & Note \\
\hline $\begin{array}{l}\text { Khosla et al. } \\
{[64]}\end{array}$ & 2012 & 8 & Retrospective & Primary disease & $\begin{array}{l}\text { Primary surgery } \\
\text { in } 3 \text { patients } \pm \mathrm{CT} \\
\pm \mathrm{RT} \\
\text { Primary RT } 2 \text { in } 2 \\
\text { patients } \\
3 \text { patients } \\
\text { absconded after } \\
\text { diagnosis }\end{array}$ & $\begin{array}{l}3 \text { patients }(37.3 \%) \text { alive } \\
\text { without disease. } \\
2(25 \%) \text { disease } \\
\text { related death. } \\
3(37.5 \%) \text { lost at FU }\end{array}$ & $\begin{array}{l}\text { The optimal } \\
\text { management of } \\
\text { these tumors is } \\
\text { uncertain owing to } \\
\text { its rarity; however, } \\
\text { combined modality } \\
\text { treatment can } \\
\text { result in prolonged } \\
\text { survival. }\end{array}$ & $\begin{array}{l}\text { Patients treated } \\
\text { from } 2006 \text { to } \\
2009\end{array}$ \\
\hline $\begin{array}{l}\text { Bansal et al. } \\
{[65]}\end{array}$ & 2010 & 323 & Retrospective & $\begin{array}{l}\text { Primary disease. } \\
\text { Comparison of } \\
\text { outcome with } \\
\text { adenocarcinoma } \\
\text { and squamous cell } \\
\text { cervical cancer }\end{array}$ & NR & $\begin{array}{l}5 \text { years OS: } \\
\text { FIGO Stage IA } 95 \% \\
(95 \% \text { CI, } 94-95 \%) \text { for } \\
\text { squamous neoplasms vs } \\
80 \%(95 \% \text {, CI } 39-95 \%) \\
\text { for sarcomas; } \\
\text { FIGO stage IB } 80 \% \\
(95 \%, \text { CI } 79-81 \%) \text { for } \\
\text { squamous neoplasms vs } \\
67 \%(95 \%, \text { CI } 58-75 \%) \\
\text { for sarcomas; FIGO } \\
\text { stage III 32\% (95\%, CI } \\
30-34 \%) \text { for squamous } \\
\text { neoplasms vs 20\% } \\
(95 \%, \text { CI 7-39\%) for } \\
\text { sarcomas }\end{array}$ & $\begin{array}{l}\text { The prognosis } \\
\text { for women with } \\
\text { cervical sarcomas } \\
\text { is inferior to that of } \\
\text { squamous cell and } \\
\text { adenocarcinomas } \\
\text { matched by stage. }\end{array}$ & $\begin{array}{l}\text { National Cancer } \\
\text { Institute's } \\
\text { Surveillance, } \\
\text { Epidemiology, } \\
\text { and End Results } \\
\text { Program } \\
(1988-2005)\end{array}$ \\
\hline $\begin{array}{l}\text { Kriseman et } \\
\text { al. [66] }\end{array}$ & 2012 & 11 & Retrospective & $\begin{array}{l}\text { Primary disease. } \\
\text { Cervical } \\
\text { rhabdomyosarcoma }\end{array}$ & $\begin{array}{l}\text { Surgery in } 9 \\
\text { patients, CT in } 2 \\
\text { patients }\end{array}$ & $\begin{array}{l}\text { At a median follow-up } \\
\text { of } 23 \text { months (range, } \\
1-176 \text { months), } 3 \\
\text { patients ( } 27 \% \text { ) recurred. } \\
1 \text { patient died for } \\
\text { chemotherapy related } \\
\text { complications after } \\
\text { recurrence. } \\
\text { At last FU } 1 \text { patient } \\
\text { who recurred died of } \\
\text { disease. } \\
\text { Of the } 8 \text { patients who } \\
\text { did not recur, } 2 \text { deaths } \\
\text { were recorded ( } 1 \text { for } \\
\text { unknown cause and } 1 \\
\text { for a different cancer), } \\
6 \text { patients were alive } \\
\text { without disease }\end{array}$ & $\begin{array}{l}\text { Surgery and } \\
\text { chemotherapy } \\
\text { are the mainstays } \\
\text { of treatment } \\
\text { of cervical } \\
\text { rhabdomyosarcoma, } \\
\text { and the prognosis of } \\
\text { patients treated with } \\
\text { multimodal therapy } \\
\text { is good }\end{array}$ & $\begin{array}{l}\text { Patients } \\
\text { treated from } \\
1980-2010\end{array}$ \\
\hline $\begin{array}{l}\text { Ditto et al. } \\
{[68]}\end{array}$ & 2013 & 1 & Case report & $\begin{array}{l}\text { Primary disease. } \\
\text { Cervical } \\
\text { rhabdomyosarcoma }\end{array}$ & $\begin{array}{l}\text { Surgery + CT } \\
+\mathrm{RT}\end{array}$ & $\begin{array}{l}\text { No evidence of } \\
\text { recurrence at a follow } \\
\text { up of } 46 \text { months }\end{array}$ & - & - \\
\hline Li et al. [69] & 2011 & 3 & Retrospective & $\begin{array}{l}\text { Primary disease. } \\
\text { Radical abdominal } \\
\text { trachelectomy } \\
\text { in cervical } \\
\text { malignancies }\end{array}$ & Surgery & $\begin{array}{l}\text { No recurrence at } \\
\text { median follow up of } \\
22.8 \text { months (range } \\
1-78 \text { months) }\end{array}$ & $\begin{array}{l}\text { The surgical, } \\
\text { oncological and } \\
\text { fertility outcomes of } \\
\text { this study suggested } \\
\text { radical abdominal } \\
\text { trachelectomy as } \\
\text { an appropriate } \\
\text { management } \\
\text { for cervical } \\
\text { malignancies }\end{array}$ & $\begin{array}{l}\text { Patients treated } \\
\text { from } 2004 \text { to } \\
2010\end{array}$ \\
\hline $\begin{array}{l}\text { Irvin et al. } \\
{[70]}\end{array}$ & 2003 & 1 & Case report & $\begin{array}{l}\text { Cervical } \\
\text { leiomyosarcoma }\end{array}$ & Surgery + RT & $\begin{array}{l}\text { At } 5 \text { years follow up } \\
\text { No evidence of disease }\end{array}$ & - & - \\
\hline
\end{tabular}

CT: chemotherapy; RT: radiotherapy; NR: not reported; OS: overall survival

As mentioned before, vulval epitheliod sarcoma is considered to have a high rate of local relapses, regional nodal spread and distant metastases. For this aggressive disease, the role of apparently negative groin lymph node dissection is still debated [78]. In the same way, evidences on removal of enlarged groin nodes are controversial [79].

Overall, standard management of vulval sarcomas is still not well established due to their rarity. However, surgery with free margins is the cornerstone of treatment. The width of the margin is still not fully defined but, basing on data from extragenital location, $2 \mathrm{~cm}$ is considered sufficient [80]. If systematic groin node dissection or removal of enlarged groin nodes has a benefit on survival is still debated and further evidences are needed. The role of adjuvant treatment has been advocated for patients with close surgical margins, residual tumour or high-grade disease [80]. 
Table 6: Overview of main studies on the role of surgery in vulval and vaginal sarcomas

\begin{tabular}{|c|c|c|c|c|c|c|c|c|}
\hline Author & Year & $\begin{array}{c}\text { Number } \\
\text { of } \\
\text { patients }\end{array}$ & Type of study & Setting & Treatment & Survival & Conclusion & Note \\
\hline Nasioudis et al. [73] & 2017 & 144 & Retrospective & $\begin{array}{l}\text { Rhabdomyosarcoma } \\
\text { of lower genital } \\
\text { tract }\end{array}$ & $\begin{array}{l}\text { Surgery }+ \\
\text { adjuvant CT }\end{array}$ & $\begin{array}{l}\text { 5-year OS } 68.4 \% \text {. } \\
\text { Median OS for } \\
\text { women with stage } \\
\text { IV RMS was } 8 \\
\text { months ( } 95 \% \text { CI } \\
0,26.6)\end{array}$ & $\begin{array}{l}\text { Prepubertal and } \\
\text { adolescent age } \\
\text { display greater } \\
\text { survival rates. } \\
\text { Older age, } \\
\text { advanced stage } \\
\text { disease and } \\
\text { non-embryonal } \\
\text { histologic subtypes } \\
\text { are associated with } \\
\text { inferior outcomes. }\end{array}$ & $\begin{array}{l}\text { National } \\
\text { Cancer } \\
\text { Institute's } \\
\text { Surveillance, } \\
\text { Epidemiology, } \\
\text { and End } \\
\text { Results } \\
\text { Program } \\
(1973-2013)\end{array}$ \\
\hline $\begin{array}{l}\text { González-Bugatto } \\
\text { et al. }[74]\end{array}$ & 2009 & 1 & Case report & $\begin{array}{l}\text { Vulval } \\
\text { leiomyosarcoma } \\
\text { arising in } \\
\text { Bartholin's gland }\end{array}$ & Surgical excision & $\begin{array}{l}\text { Recurrence } 12 \\
\text { months after } \\
\text { surgery. } \\
\text { Alive after } 5 \text { years } \\
\text { of follow up }\end{array}$ & - & - \\
\hline Curtin et al. [77] & 1995 & 24 & Retrospective & $\begin{array}{l}\text { Primary disease. } \\
\text { Vaginal and vulval } \\
\text { sarcomas }\end{array}$ & $\begin{array}{l}\text { Surgery in } 22 \\
\text { patients }\end{array}$ & $\begin{array}{l}16 \text { patients were } \\
(70 \%) \text { are free } \\
\text { of disease at a } \\
\text { median follow-up } \\
\text { time of } 47 \text { months } \\
\text { (range } 12-156, \\
\text { mean } 59 \text { ). Five } \\
\text { women died of } \\
\text { progressive disease } \\
\text { and two were alive } \\
\text { al last follow up } \\
\text { with persistent or } \\
\text { recurrent disease }\end{array}$ & - & $\begin{array}{l}\text { Patients treated } \\
\text { from } 1974 \text { to } \\
1993\end{array}$ \\
\hline Kim et al. [79] & 2008 & 1 & Case report & $\begin{array}{l}\text { Primary disease. } \\
\text { Vulval epithelioid } \\
\text { sarcoma }\end{array}$ & $\begin{array}{l}\text { Wide local } \\
\text { excision }\end{array}$ & $\begin{array}{l}\text { Alive at } 8 \text { months } \\
\text { follow up }\end{array}$ & - & - \\
\hline Ulutin et al. [80] & 2003 & 7 & Retrospective & $\begin{array}{l}\text { Primary disease. } \\
\text { Vulval soft tissue } \\
\text { sarcoma }\end{array}$ & $\begin{array}{l}\text { Surgery } \pm \text { groin } \\
\text { lymph node } \\
\text { dissection } \pm \\
\text { adjuvant RT }\end{array}$ & $\begin{array}{l}\text { No recurrence after } \\
\text { a median follow up } \\
\text { of } 127.8 \text { months }\end{array}$ & - & $\begin{array}{l}\text { Data from } \\
\text { Sidney } \\
\text { Kimmel } \\
\text { Comprehensive } \\
\text { Cancer tumour } \\
\text { registry. } \\
\text { Patients treated } \\
\text { from } 1977 \text { to } \\
1997\end{array}$ \\
\hline Ghada et al. [83] & 2017 & 1 & Case report & $\begin{array}{l}\text { Primary ESS arising } \\
\text { in the vagina }\end{array}$ & $\begin{array}{l}\text { Surgery }+ \\
\text { hormonal } \\
\text { treatment }\end{array}$ & $\begin{array}{l}\text { No recurrence } \\
\text { after } 7 \text { months of } \\
\text { follow up }\end{array}$ & - & - \\
\hline
\end{tabular}

OS: overall survival; CT: chemotherapy; RT: radiotherapy; ESS: endometrial stromal sarcoma

\section{Vaginal sarcomas}

Vaginal sarcomas are infrequent entities which can also occur in pediatric patients. Different histotypes are described in literature, although very limited data are available due to their rarity. In a retrospective review of 144 cases of rhabdomyosarcoma of lower female genital tract, Nasioudis et al identified 74 women (54.4\%) with vaginal or vulval rhabdomyosarcoma with an overall patient's median age of 16 years (range, 1-87) [73]. Embryonal rhabdomyosarcoma is the most common subtype, for which radical surgery has been mostly replaced with chemotherapy, radiation treatment and conservative surgery. On this topic, a case of vaginoscopic resection of vaginal rhabdomyosarcoma during infancy has been reported [81]. Among paediatric tumours, 11 cases of extra-osseus primary Ewing sarcoma of the vagina have been described in literature. For those patients, surgical treatment is an option only in absence of distant metastases [82].
ESS rarely occur outside the uterus and even more rarely they arise in the vagina. At best of our knowledge, only seven cases have been described not in association with endometriosis. Due to the infrequency of the disease, there are not specific guidelines to follow and for this reason treatment is mainly based on previous case reports and treatment guidelines of ESS [83].

Feasibility of laparoscopic surgery in this setting in opposition to laparotomy has been recently described by Pontrelli et al [84], who reported no recurrence at a follow up of 29 months after complete laparoscopic resection of a vaginal adenosarcoma.

Table 6 shows an overview of main studies on the role of surgery in vulval and vaginal sarcomas.

\section{CONCLUSIONS}

Gynaecological sarcomas represent a wide spectrum of neoplasms that, due to their rarity, are still 
partially obscure. For all of them, surgical treatment is the cornerstone of care providing survival advantage, despite the prognosis is poor. Other additional treatment strategies such as chemotherapy and radiotherapy are available for these patients, although their role has not been investigated in this review. Prospective data are needed to better characterise these uncommon entities and to potentially standardise treatment modalities worldwide.

\section{CONFLICTS OF INTEREST}

None.

\section{FUNDING}

No financial support has been received for this manuscript.

\section{REFERENCES}

1. Francis M, Dennis NL, Hirschowitz L, Grimer R, Poole J, Lawrence G, Nordin A. Incidence and survival of gynecologic sarcomas in England. Int $\mathrm{J}$ Gynecol Cancer. 2015; 25:850-57. https://doi.org/10.1097/ $\underline{\text { IGC.0000000000000443. [PubMed] }}$

2. National Cancer Intelligence Network. Gynaecological Sarcoma Surgical Treatment. 2014. Available from: http:// www.ncin.org. uk/view?rid=2755.

3. Ricci S, Stone RL, Fader AN. Uterine leiomyosarcoma: Epidemiology, contemporary treatment strategies and the impact of uterine morcellation. Gynecol Oncol. 2017; 145:208-16. https://doi.org/10.1016/j.ygyno.2017.02.019. [PubMed]

4. Amant F, Coosemans A, Debiec-Rychter M, Timmerman D, Vergote I. Clinical management of uterine sarcomas. Lancet Oncol. 2009; 10:1188-98. https://doi.org/10.1016/ S1470-2045(09)70226-8. [PubMed]

5. Koh WJ, Abu-Rustum NR, Bean S, Bradley K, Campos SM, Cho KR, Chon HS, Chu C, Cohn D, Crispens MA, Damast $\mathrm{S}$, Dorigo O, Eifel PJ, et al. Uterine Neoplasms, Version 1.2018, NCCN Clinical Practice Guidelines in Oncology. J Natl Compr Canc Netw. 2018; 16:170-99. https://doi. org/10.6004/jncen.2018.0006. [PubMed]

6. Bansal N, Herzog TJ, Burke W, Cohen CJ, Wright JD. The utility of preoperative endometrial sampling for the detection of uterine sarcomas. Gynecol Oncol. 2008; 110:43-48. https://doi.org/10.1016/j.ygyno.2008.02.026. [PubMed]

7. Thomassin-Naggara I, Dechoux S, Bonneau C, Morel A, Rouzier R, Carette MF, Daraï E, Bazot M. How to differentiate benign from malignant myometrial tumours using MR imaging. Eur Radiol. 2013; 23:2306-14. https:// doi.org/10.1007/s00330-013-2819-9. [PubMed]

8. Barral M, Placé V, Dautry R, Bendavid S, Cornelis F, Foucher R, Guerrache Y, Soyer P. Magnetic resonance imaging features of uterine sarcoma and mimickers. Abdom
Radiol (NY). 2017; 42:1762-72. https://doi.org/10.1007/ s00261-017-1076-9. [PubMed]

9. Exacoustos $\mathrm{C}$, Romanini $\mathrm{ME}$, Amadio A, Amoroso C, Szabolcs B, Zupi E, Arduini D. Can gray-scale and color Doppler sonography differentiate between uterine leiomyosarcoma and leiomyoma? J Clin Ultrasound. 2007; 35:449-57. https://doi.org/10.1002/jcu.20386. [PubMed]

10. Nagai $T$, Takai $Y$, Akahori $T$, Ishida $H$, Hanaoka $T$, Uotani T, Sato S, Matsunaga S, Baba K, Seki H. Novel uterine sarcoma preoperative diagnosis score predicts the need for surgery in patients presenting with a uterine mass. Springerplus. 2014; 3:678. https://doi.org/10.1186/21931801-3-678. [PubMed]

11. Seki K, Hoshihara T, Nagata I. Leiomyosarcoma of the uterus: ultrasonography and serum lactate dehydrogenase level. Gynecol Obstet Invest. 1992; 33:114-18. https://doi. org/10.1159/000294861. [PubMed]

12. Kawamura N, Ichimura $\mathrm{T}$, Ito $\mathrm{F}$, Shibata $\mathrm{S}$, Takahashi $\mathrm{K}$, Tsujimura A, Ishiko O, Haba T, Wakasa K, Ogita S. Transcervical needle biopsy for the differential diagnosis between uterine sarcoma and leiomyoma. Cancer. 2002; 94:1713-20. https://doi.org/10.1002/cncr.10382. [PubMed]

13. Tamura R, Kashima K, Asatani M, Nishino K, Nishikawa N, Sekine M, Serikawa T, Enomoto T. Preoperative ultrasoundguided needle biopsy of 63 uterine tumors having high signal intensity upon T2-weighted magnetic resonance imaging. Int J Gynecol Cancer. 2014; 24:1042-47. https:// doi.org/10.1097/IGC.0000000000000189. [PubMed]

14. Koh WJ, Greer BE, Abu-Rustum NR, Apte SM, Campos SM, Cho KR, Chu C, Cohn D, Crispens MA, Dizon DS, Dorigo O, Eifel PJ, Fisher CM, et al, and National Comprehensive Cancer Network. Uterine Sarcoma, Version 1.2016: Featured Updates to the NCCN Guidelines. J Natl Compr Canc Netw. 2015; 13:1321-31. https://doi. org/10.6004/jncen.2015.0162. [PubMed]

15. Benson $\mathrm{C}$, Miah $\mathrm{AB}$. Uterine sarcoma - current perspectives. Int J Womens Health. 2017; 9:597-606. https://doi. org/10.2147/IJWH.S117754. [PubMed]

16. Barney B, Tward JD, Skidmore T, Gaffney DK. Does radiotherapy or lymphadenectomy improve survival in endometrial stromal sarcoma? Int J Gynecol Cancer. 2009; 19:1232-38. https://doi.org/10.1111/IGC.0b013e3181b33c9a. [PubMed]

17. Seagle BL, Sobecki-Rausch J, Strohl AE, Shilpi A, Grace A, Shahabi S. Prognosis and treatment of uterine leiomyosarcoma: A National Cancer Database study. Gynecol Oncol. 2017; 145:61-70. https://doi.org/10.1016/j. ygyno.2017.02.012. [PubMed]

18. Kapp DS, Shin JY, Chan JK. Prognostic factors and survival in 1396 patients with uterine leiomyosarcomas: emphasis on impact of lymphadenectomy and oophorectomy. Cancer. 2008; 112:820-30. https://doi.org/10.1002/cncr.23245. [PubMed]

19. Leitao MM, Sonoda Y, Brennan MF, Barakat RR, Chi DS. Incidence of lymph node and ovarian metastases in 
leiomyosarcoma of the uterus. Gynecol Oncol. 2003; 91:209-12. https://doi.org/10.1016/S0090-8258(03)004785. [PubMed]

20. Stewart LE, Beck TL, Giannakopoulos NV, Rendi MH, Isacson C, Goff BA. Impact of oophorectomy and hormone suppression in low grade endometrial stromal sarcoma: A multicenter review. Gynecol Oncol. 2018; 149:297-300. https://doi.org/10.1016/j.ygyno.2018.03.008. [PubMed]

21. Nasioudis D, Chapman-Davis E, Frey M, Holcomb K. Safety of ovarian preservation in premenopausal women with stage I uterine sarcoma. J Gynecol Oncol. 2017; 28:e46. https://doi.org/10.3802/igo.2017.28.e46. [PubMed]

22. Shah JP, Bryant CS, Kumar S, Ali-Fehmi R, Malone JM $\mathrm{Jr}$, Morris RT. Lymphadenectomy and ovarian preservation in low-grade endometrial stromal sarcoma. Obstet Gynecol. 2008; 112:1102-08. https://doi.org/10.1097/ AOG.0b013e31818aa89a. [PubMed]

23. Bai H, Yang J, Cao D, Huang H, Xiang Y, Wu M, Cui Q, Chen J, Lang J, Shen K. Ovary and uterus-sparing procedures for low-grade endometrial stromal sarcoma: a retrospective study of 153 cases. Gynecol Oncol. 2014; 132:654-60. https://doi.org/10.1016/j.ygyno.2013.12.032. [PubMed]

24. Philip CA, Pautier P, Duffaud F, Ray-Coquard I. Highgrade undifferentiated sarcomas of the uterus: diagnosis, outcomes, and new treatment approaches. Curr Oncol Rep. 2014; 16:405. https://doi.org/10.1007/s11912-014-0405-1. [PubMed]

25. Updated laparoscopic uterine power morcellation in hysterectomy and myomectomy: FDA safety communication. Available from: https://www.fda. gov/medicaldevices/productsandmedicalprocedures/ surgeryandlifesupport/ucm584463.htm.

26. Pritts EA, Parker WH, Brown J, Olive DL. Outcome of occult uterine leiomyosarcoma after surgery for presumed uterine fibroids: a systematic review. J Minim Invasive Gynecol. 2015; 22:26-33. https://doi.org/10.1016/j. jmig.2014.08.781. [PubMed]

27. Kho KA, Lin K, Hechanova M, Richardson DL. Risk of occult uterine sarcoma in women undergoing hysterectomy for benign indications. Obstet Gynecol. 2016; 127:468-73. https://doi.org/10.1097/AOG.0000000000001242. [PubMed]

28. Ricci S, Angarita A, Cholakian D, Ramos A, Sinno AK, Long KC, Tanner EJ 3rd, Stone RL, Levinson K, Nickles Fader A. Preoperative patient stratification results in low rates of occult uterine malignancy in women undergoing uterine surgery and morcellation. Gynecol Oncol. 2015; 137:11-12. https://doi.org/10.1016/j.ygyno.2015.01.025.

29. Mahnert N, Morgan D, Campbell D, Johnston C, As-Sanie $\mathrm{S}$. Unexpected gynecologic malignancy diagnosed after hysterectomy performed for benign indications. Obstet Gynecol. 2015; 125:397-405. https://doi.org/10.1097/ AOG.0000000000000642. [PubMed]

30. Lieng M, Berner E, Busund B. Risk of morcellation of uterine leiomyosarcomas in laparoscopic supracervical hysterectomy and laparoscopic myomectomy, a retrospective trial including 4791 women. J Minim Invasive Gynecol. 2015; 22:410-14. https://doi.org/10.1016/j. jmig.2014.10.022. [PubMed]

31. Bogani G, Cliby WA, Aletti GD. Impact of morcellation on survival outcomes of patients with unexpected uterine leiomyosarcoma: a systematic review and metaanalysis. Gynecol Oncol. 2015; 137:167-72. https://doi. org/10.1016/j.ygyno.2014.11.011. [PubMed]

32. Raspagliesi F, Maltese G, Bogani G, Fucà G, Lepori S, De Iaco P, Perrone M, Scambia G, Cormio G, Bogliolo S, Bergamini A, Bifulco G, Casali PG, Lorusso D. Morcellation worsens survival outcomes in patients with undiagnosed uterine leiomyosarcomas: A retrospective MITO group study. Gynecol Oncol. 2017; 144:90-95. https://doi.org/10.1016/j.ygyno.2016.11.002. [PubMed]

33. Bogani G, Ditto A, Martinelli F, Signorelli M, Chiappa V, Lorusso D, Sabatucci I, Carcangiu ML, Fiore M, Gronchi A, Raspagliesi F. Morcellator's Port-site Metastasis of a Uterine Smooth Muscle Tumor of Uncertain Malignant Potential After Minimally Invasive Myomectomy. J Minim Invasive Gynecol. 2016; 23:647-49. https://doi. org/10.1016/i.jmig.2016.01.021. [PubMed]

34. Bogani G, Chiappa V, Ditto A, Martinelli F, Signorelli M, Lorusso D, Raspagliesi F. Morcellation of apparent benign uterine myoma: assessing risk to benefit ratio. J Gynecol Oncol. 2016; 27:e37. https://doi.org/10.3802/jgo.2016.27. e37. [PubMed]

35. Einstein MH, Barakat RR, Chi DS, Sonoda Y, Alektiar KM, Hensley ML, Abu-Rustum NR. Management of uterine malignancy found incidentally after supracervical hysterectomy or uterine morcellation for presumed benign disease. Int J Gynecol Cancer. 2008; 18:1065-70. https:// doi.org/10.1111/j.1525-1438.2007.01126.x. [PubMed]

36. Oduyebo T, Rauh-Hain AJ, Meserve EE, Seidman MA, Hinchcliff E, George S, Quade B, Nucci MR, Del Carmen MG, Muto MG. The value of re-exploration in patients with inadvertently morcellated uterine sarcoma. Gynecol Oncol. 2014; 132:360-65. https://doi.org/10.1016/j. ygyno.2013.11.024. [PubMed]

37. Lissoni A, Cormio G, Bonazzi C, Perego P, Lomonico S, Gabriele A, Bratina G. Fertility-sparing surgery in uterine leiomyosarcoma. Gynecol Oncol. 1998; 70:348-50. https:// doi.org/10.1006/gyno.1998.5124. [PubMed]

38. Jin Y, Li Y, Deng CY, Tian QJ, Chen H, Pan LY. Fertilitysparing treatment of low-grade endometrial stromal sarcoma. Int J Clin Exp Med. 2015; 8:5818-21. https://doi. org/10.18632/oncotarget.12491. [PubMed]

39. Yan L, Tian Y, Fu Y, Zhao X. Successful pregnancy after fertility-preserving surgery for endometrial stromal sarcoma. Fertil Steril. 2010; 93:269.e1-3. https://doi. org/10.1016/j.fertnstert.2009.09.024. [PubMed]

40. Xie W, Cao D, Yang J, Jiang X, Shen K, Pan L, Huang H, Lang J, You Y, Chen J. Fertility-sparing surgery for patients with low-grade endometrial stromal sarcoma. 
Oncotarget. 2017; 8:10602-08. https://doi.org/10.18632/ oncotarget.12491. [PubMed]

41. Dinh TA, Oliva EA, Fuller AF Jr, Lee H, Goodman A. The treatment of uterine leiomyosarcoma. Results from a 10-year experience (1990-1999) at the Massachusetts General Hospital. Gynecol Oncol. 2004; 92:648-52. https:// doi.org/10.1016/j.ygyno.2003.10.044. [PubMed]

42. Leitao MM Jr, Zivanovic O, Chi DS, Hensley ML, O'Cearbhaill R, Soslow RA, Barakat RR. Surgical cytoreduction in patients with metastatic uterine leiomyosarcoma at the time of initial diagnosis. Gynecol Oncol. 2012; 125:409-13. https://doi.org/10.1016/j. ygyno.2012.02.014. [․ㅏbMed]

43. Rauh-Hain JA, del Carmen MG. Endometrial stromal sarcoma: a systematic review. Obstet Gynecol. 2013; 122:676-83. https://doi.org/10.1097/ AOG.0b013e3182a189ac. [PubMed]

44. Giuntoli RL 2nd, Garrett-Mayer E, Bristow RE, Gostout BS. Secondary cytoreduction in the management of recurrent uterine leiomyosarcoma. Gynecol Oncol. 2007; 106:82-88. https://doi.org/10.1016/j.ygyno.2007.02.031. [PubMed]

45. Nakamura K, Kajiyama H, Utsumi F, Suzuki S, Niimi K, Sekiya R, Sakata J, Yamamoto E, Shibata K, Kikkawa F. Secondary cytoreductive surgery potentially improves the oncological outcomes of patients with recurrent uterine sarcomas. Mol Clin Oncol. 2018; 8:499-503. https://doi. org/10.3892/mco.2018.1560. [PubMed]

46. Díaz-Montes TP, El-Sharkawy F, Lynam S, Harper A, Sittig M, MacDonald R, Gushchin V, Sardi A. Efficacy of Hyperthermic Intraperitoneal Chemotherapy and Cytoreductive Surgery in the Treatment of Recurrent Uterine Sarcoma. Int J Gynecol Cancer. 2018; 28:1130-37. https://doi.org/10.1097/IGC.0000000000001289. [PubMed]

47. Tropé CG, Abeler VM, Kristensen GB. Diagnosis and treatment of sarcoma of the uterus. A review. Acta Oncol. 2012; 51:694-705. https://doi.org/10.3109/02841 86X.2012.689111. [PubMed]

48. Gadducci A. Prognostic factors in uterine sarcoma. Best Pract Res Clin Obstet Gynaecol. 2011; 25:783-95. https:// doi.org/10.1016/j.bpobgyn.2011.06.002. [PubMed]

49. Schwameis R, Grimm C, Petru E, Natter C, Staudigl C, Lamm W, Koelbl H, Krainer M, Brodowicz T, Reinthaller A, Polterauer S. The Prognostic Value of C-Reactive Protein Serum Levels in Patients with Uterine Leiomyosarcoma. PLoS One. 2015; 10:e0133838. https://doi.org/10.1371/ journal.pone.0133838. [PubMed]

50. Wu TI, Chang TC, Hsueh S, Hsu KH, Chou HH, Huang $\mathrm{HJ}$, Lai CH. Prognostic factors and impact of adjuvant chemotherapy for uterine leiomyosarcoma. Gynecol Oncol. 2006; 100:166-72. https://doi.org/10.1016/j. ygyno.2005.08.010. [PubMed]

51. Bacalbasa N, Balescu I, Dima S, Popescu I. Ovarian sarcoma carries a poorer prognosis than ovarian epithelial cancer throughout all FIGO stages: a single-center case-control matched study. Anticancer Res. 2014; 34:7303-08. [PubMed]

52. Taşkin S, Taşkin EA, Uzüm N, Ataoğlu O, Ortaç F. Primary ovarian leiomyosarcoma: a review of the clinical and immunohistochemical features of the rare tumor. Obstet Gynecol Surv. 2007; 62:480-86. https://doi.org/10.1097/01. ogx.0000268629.16151.71. [PubMed]

53. López-Ruiz ME, Yébenes L, Berjón A, Hardisson D. Primary Leiomyosarcoma of the Ovarian Vein: Case Report and Literature Review. Int J Surg Pathol. 2017; 25:339-43. https://doi.org/10.1177/1066896916679888. [PubMed]

54. Hensley ML, Barrette BA, Baumann K, Gaffney D, Hamilton AL, Kim JW, Maenpaa JU, Pautier P, Siddiqui NA, Westermann AM, Ray-Coquard I. Gynecologic Cancer InterGroup (GCIG) consensus review: uterine and ovarian leiomyosarcomas. Int J Gynecol Cancer. 2014; 24:S61-66. https://doi.org/10.1097/IGC.0000000000000261. [PubMed]

55. He M, Deng YJ, Zhao DY, Zhang Y, Wu T. Synchronous leiomyosarcoma and fibroma in a single ovary: A case report and review of the literature. Oncol Lett. 2016; 11:2510-14. https://doi.org/10.3892/ol.2016.4241. [PubMed]

56. Pongsuvareeyakul T, Sukpan K, Chaicharoen S, Khunamornpong S. Leiomyosarcoma and Squamous Cell Carcinoma Arising in Mature Cystic Teratoma of the Ovary. Case Rep Pathol. 2017; 2017:7907359. https://doi. org/10.1155/2017/7907359. [PubMed]

57. Friedman HD, Mazur MT. Primary ovarian leiomyosarcoma. An immunohistochemical and ultrastructural study. Arch Pathol Lab Med. 1991; 115:941-45.

58. Bacalbasa N, Taras C, Orban C, Iliescu L, Hurjui I, Hurjui M, Niculescu N, Cristea M, Balescu I. Atypical Right Hepatectomy for Liver Metastasis from Ovarian Leiomyosarcoma - A Case Report and Literature Review. Anticancer Res. 2016; 36:1835-40. [PubMed]

59. Sultana N, Pikaart DP, Ahmad S, DeNardis SA, Finkler NJ. Paraovarian leiomyosarcoma with scalp metastasis: a case report. Eur J Gynaecol Oncol. 2009; 30:566-67. [PubMed]

60. Rasmussen CC, Skilling JS, Sorosky JI, Lager DJ, Buller RE. Stage IIIC ovarian leiomyosarcoma in a premenopausal woman with multiple recurrences: prolonged survival with surgical therapy. Gynecol Oncol. 1997; 66:519-25. https:// doi.org/10.1006/gyno.1997.4824. [PubMed]

61. Xie W, Bi X, Cao D, Yang J, Shen K, You Y. Primary endometrioid stromal sarcomas of the ovary: a clinicopathological study of 14 cases with a review of the literature. Oncotarget. 2017; 8:63345-52. https://doi. org/10.18632/oncotarget.18805. [ubMed]

62. Geas FL, Tewari DS, Rutgers JK, Tewari KS, Berman ML. Surgical cytoreduction and hormone therapy of an advanced endometrial stromal sarcoma of the ovary. Obstet Gynecol. 2004; 103:1051-54. https://doi.org/10.1097/01. AOG.0000127942.91516.a2. [PubMed]

63. Fadare O. Uncommon sarcomas of the uterine cervix: a review of selected entities. Diagn Pathol. 2006; 1:30. https://doi.org/10.1186/1746-1596-1-30. [PubMed] 
64. Khosla D, Gupta R, Srinivasan R, Patel FD, Rajwanshi A. Sarcomas of uterine cervix: clinicopathological features, treatment, and outcome. Int $\mathrm{J}$ Gynecol Cancer. 2012; 22:1026-30. https://doi.org/10.1097/ IGC.0b013e31825a97f6. [PubMed]

65. Bansal S, Lewin SN, Burke WM, Deutsch I, Sun X, Herzog TJ, Wright JD. Sarcoma of the cervix: natural history and outcomes. Gynecol Oncol. 2010; 118:134-38. https://doi. org/10.1016/j.ygyno.2010.04.021. [PubMed]

66. Kriseman ML, Wang WL, Sullinger J, Schmeler KM, Ramirez PT, Herzog CE, Frumovitz M. Rhabdomyosarcoma of the cervix in adult women and younger patients. Gynecol Oncol. 2012; 126:351-56. https://doi.org/10.1016/j. ygyno.2012.05.008. [PubMed]

67. Ghaemmaghami F, Karimi Zarchi M, Ghasemi M. Lower genital tract rhabdomyosarcoma: case series and literature review. Arch Gynecol Obstet. 2008; 278:65-69. https://doi. org/10.1007/s00404-007-0503-5. [PubMed]

68. Ditto A, Martinelli F, Carcangiu M, Solima E, de Carrillo KJ, Sanfilippo R, Haeusler E, Raspagliesi F. Embryonal rhabdomyosarcoma of the uterine cervix in adults: a case report and literature review. J Low Genit Tract Dis. 2013; 17:e12-17. https://doi.org/10.1097/ LGT.0b013e31827a8b8c. [PubMed]

69. Li J, Li Z, Wang H, Zang R, Zhou Y, Ju X, Ke G, Wu X. Radical abdominal trachelectomy for cervical malignancies: surgical, oncological and fertility outcomes in 62 patients. Gynecol Oncol. 2011; 121:565-70. https://doi. org/10.1016/j.ygyno.2011.01.032. [PubMed]

70. Irvin W, Presley A, Andersen W, Taylor P, Rice L. Leiomyosarcoma of the cervix. Gynecol Oncol. 2003; 91:636-42. https://doi.org/10.1016/j.ygyno.2003.08.037. [PubMed]

71. Chokoeva AA, Tchernev G, Cardoso JC, Patterson JW, Dechev I, Valkanov S, Zanardelli M, Lotti T, Wollina U. Vulvar sarcomas: short guideline for histopathological recognition and clinical management. Part 1. Int J Immunopathol Pharmacol. 2015; 28:168-77. https://doi. org $/ 10.1177 / 0394632015576029$. [PubMed]

72. Chokoeva AA, Tchernev G, Cardoso JC, Patterson JW, Dechev I, Valkanov S, Zanardelli M, Lotti T, Wollina U. Vulvar sarcomas: short guideline for histopathological recognition and clinical management. Part 2. Int J Immunopathol Pharmacol. 2015; 28:178-86. https://doi. org $/ 10.1177 / 0394632015575977$. [PubMed]

73. Nasioudis D, Alevizakos M, Chapman-Davis E, Witkin SS, Holcomb K. Rhabdomyosarcoma of the lower female genital tract: an analysis of 144 cases. Arch Gynecol Obstet. 2017; 296:327-34. https://doi.org/10.1007/s00404-0174438-1. [PubMed]

74. González-Bugatto F, Añón-Requena MJ, López-Guerrero MA, Báez-Perea JM, Bartha JL, Hervías-Vivancos B. Vulvar leiomyosarcoma in Bartholin's gland area: a case report and literature review. Arch Gynecol Obstet. 2009; 279:171-74. https://doi.org/10.1007/s00404-008-0652-1. [PubMed]

75. Nielsen GP, Rosenberg AE, Koerner FC, Young RH, Scully RE. Smooth-muscle tumors of the vulva. A clinicopathological study of 25 cases and review of the literature. Am J Surg Pathol. 1996; 20:779-93. https://doi. org/10.1097/00000478-199607000-00001. [PubMed]

76. Aartsen EJ, Albus-Lutter CE. Vulvar sarcoma: clinical implications. Eur J Obstet Gynecol Reprod Biol. 1994; 56:181-89. https://doi.org/10.1016/0028-2243(94)901686. [PubMed]

77. Curtin JP, Saigo P, Slucher B, Venkatraman ES, Mychalczak B, Hoskins WJ. Soft-tissue sarcoma of the vagina and vulva: a clinicopathologic study. Obstet Gynecol. 1995; 86:269-72. https://doi.org/10.1016/0029-7844(95)00160-S. [PubMed]

78. Iavazzo C, Gkegkes ID, Vrachnis N. Dilemmas in the management of patients with vulval epithelioid sarcoma: a literature review. Eur J Obstet Gynecol Reprod Biol. 2014; 176:1-4. $\quad$ https://doi.org/10.1016/j.ejogrb.2014.02.013. [PubMed]

79. Kim JH, Choi YS, Lee TS. A case of epithelioid sarcoma arising in the vulva. J Gynecol Oncol. 2008; 19:202-04. https://doi.org/10.3802/jgo.2008.19.3.202. [PubMed]

80. Ulutin HC, Zellars RC, Frassica D. Soft tissue sarcoma of the vulva: A clinical study. Int J Gynecol Cancer. 2003; 13:528-31. https://doi.org/10.1136/ijgc-00009577200307000-00020. [PubMed]

81. Pańczak K, Gawron D, Sosnowska P, Kapczuk K, Mańkowski P. Vaginoscopic Resection for Vaginal Rhabdomyosarcoma during Early Infancy: A Case Report. J Minim Invasive Gynecol. 2018; 25:533-36. https://doi. org/10.1016/j.jmig.2017.07.032. [PubMed]

82. Cross NM, Stanescu AL, Rudzinski ER, Hawkins DS, Parisi MT. Vaginal Ewing Sarcoma: An Uncommon Clinical Entity in Pediatric Patients. J Clin Imaging Sci. 2017; 7:17. https://doi.org/10.4103/jcis.JCIS_96_16. [PubMed]

83. Abu Jamea GA, Al Rikabi AC, Akkour K. Primary lowgrade endometrial stromal sarcoma arising in the vagina: report of an unusual case and literature review. J Surg Case Rep. 2017; 2017:rjx238. https://doi.org/10.1093/jscr/rjx238. [PubMed]

84. Pontrelli G, Cozzolino M, Stepniewska A, Bruni F, Pesci A, Ceccaroni M. Primary Vaginal Adenosarcoma With Sarcomatous Overgrowth Arising in Recurrent Endometriosis: Feasibility of Laparoscopic Treatment and Review of the Literature. J Minim Invasive Gynecol. 2016; 23:833-38. https://doi.org/10.1016/j.jmig.2016.03.019. [PubMed] 